\title{
En naturvidenskabelig universitetsundervisers forventninger til en e-learning-platform?
}

\author{
Hannah Kamstrup Wermuth, \\ Naturvidenskabeligt IT Kompetencecenter (NIK), \\ Københavns Universitet
}

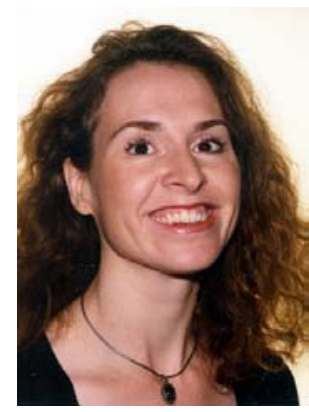

Alle danske højere læreanstalter tilbyder i dag en e-learning-platform, men hvilke krav kan man egentlig stille til en sådan, og i hvilken sammenhæng skal den bruges? Artiklen giver et bud på dette set på baggrund af erfaringer fra et naturvidenskabeligt IT-kompetencecenter.

Kravene til fremtidens undervisning går i retning af fleksibel læring, med større fokus på den studerendes individuelle behov og tilegnelse af kompetencer, og på en pædagogik, der i højere grad kvalificerer de studerende til at tage hånd om egen læring.

At der er behov for at understøtte IT-baseret, fleksibel loering gennem en elearning-platform på et moderne universitet bekraftes af Collis \& Moonen, 2001, s. 67: ".. higher education institutions have a collective desire to change towards more flexible learning mediated by technology".

Tekstboks 1: Begrebsafklaring

E-learning-platform

Begrebet "e-learning-platform" anvendes som en bred beskrivelse for de systemer der omtales. Der er tale om software, der understøtter interaktiv læring gennem webbaseret adgang til undervisningsressourcer, samarbejde og kommunikation - uafhængigt af tid og sted - samt løbende opsamling af data om et undervisningsforløb, evalueringer etc. Indenfor fagområdet elearning dækker dette begreb over en række forskellige typer af værktøjer: Learning Management Systems (LMS), Learning Content Management Systems (LCMS), Virtual Classrooms, forfatterværktøjer, kollaborative værktøjer m.m.
Med en e-learning-platform gives underviseren nye muligheder for at formidle, og den studerende nye muligheder for at blive understøttet på flere forskellige læringsniveauer. Den studerende har mulighed for en langt højere detaljeringsgrad i spørgsmålet om synliggørelse af læringsprocesser og refleksion over egen læring, fx. via simpel systemisk logning af aktiviteter, eller alternativt $i$ form af en decideret logbogs-funktionalitet. I tilknytning hertil er det oplagt at integrere såvel generel som specifik studievejledning, ligesom karrierevejleding også ville være et interessant tilbud.

Anvendelsen af en e-learning-platform giver oplagte muligheder for at nytænke det traditionelle studiemiljø, hvor potentialet i samarbejde på tværs af både lokale og globale grænser udnyttes. En e-learning-platform vil være et oplagt

forum til at kortlægge og samle fagligt interessante og relevante ressourcer både fra andre universiteter og fra erhvervslivet.

I tilknytning til ovenstående giver en e-learning-platform også mulighed for andre evalueringsteknikker, såvel til løbende evaluering af den studerende som til slutevaluering og evaluering af selve kurset. Integrering af multimedier i undervisningen er ét af de forhold, der kan styrke formidlings- og læringsprocessen, navnligt i emner, der i den traditionelle undervisningsform er svært tilgængelige. 


\section{Hvilken e-learning-platform skal man vælge?}

Københavns Universitet tilbyder i dag sine undervisere at bruge Blackboard. Der er tale om den mindste version af Blackboard, der ikke kan integreres med universitetets administrative systemer, hvori persondata og studieoplysninger ligger. KU skal på sigt satse på en løsning der kan integreres med de administrative systemer for at opfylde et primært behov hos undervisere og administrativt personale. Da Naturvidenskabeligt IT Kompetencecenter (NIK) har som en af sine opgaver at fremme relevante IT-anvendelser i undervisningen, har det været oplagt for os at udarbejde en kravspecifikation, der imødekommer de naturvidenskabelige undervisere og studerendes krav til en elearning-platform.

Udformningen af systemkrav er sket gennem en iterativ proces. Opstillingen af vore krav påbegyndtes i december 2002 og er sket dels ved gennemgang af litteratur og websites på området, og dels ved konsultation af kolleger på en række centre og institutioner, konsulenter fra firmaerne bag de undersøgte e-learning-platforme m.fl. Endvidere har både de undervisere der har deltaget i NIKs kurser i Blackboard og de undervisere der på anden vis har brugt Blackboard i deres undervisning stillet mange kritiske spørgsmål til systemet; men også fremhævet positive sider af platformen. Alt dette er blevet inddraget i udviklingen af kravspecifikationen.

\section{Tekniske og organisatoriske krav til platformen}

Hvis e-learning-platformen skal være let at gå til, uhindret skal kunne bruges af en organisation med en blanding af nye og ældre pc'ere, forskellige styresystemer, hurtige og langsomme forbindelser til Internettet, og der skal være tryghed om brugen, finder vi det nødvendigt,

1. at platformen giver mulighed for sammenkobling med administrative data,

2. at platformen ikke kræver særlige programmer installeret, men kan afvikles direkte i en browser,

3. at platformen dækker brugere der spreder sig over alle styresystemer (Windows, Mac, Unix, Linux). Dog vil det være nødvendigt at begrænse sig til nyere browsere, og dermed også nyere versioner af styresystemer,

4. at platformen kan tilgås med en opkobling fra et $56 \mathrm{~K}$ modem,

5. at platformen kan vises på en skærm med opløsning på $800 * 600$ pixels,

6. at platformen understøtter internationalt accepterede standarder der muliggør at kurser og kursusmateriale relativt nemt kan eksporteres fra den valgte platform til en anden, såfremt der på et senere tidspunkt skulle opstå behov for at skifte til andet, samt at kurser eller kursuselementer kan importeres til det valgte platform fra andre platforme,

7. at de økonomiske forhold omkring drift, support og videreudvikling skal være afklarede og gennemskuelige, samt

8. at platformen har kørt stabilt i drift med mange (dvs. flere tusinde) brugere.

Det er endvidere ønskeligt,

9. at platformen anvendes på flere universiteter, således at der er basis for erfaringsudveksling omkring brug og videreudvikling,

10. at platformen giver valgmulighed mellem en engelsk og en dansk version for den studerende,

11. at vi selv kan få indflydelse på videreudviklingen, således at de erfaringer der opnås undervejs gennem praktisk brug eller via fx. forskning inden for HCI og e-learning kan opfølges,

12. at platformen er så fleksibel, at den kan tilpasses de pædagogiske krav, de forskellige undervisere og fag måtte stille.

13. at kunne være med til at sætte dagsordenen i den fremtidige e-learning-platformsudvikling både nationalt og internationalt, samt 
14. at organisationen bag systemet er så stor og velkonsolideret at der er basis for fortsat vedligehold og udvikling i både en nær og fjernere fremtid.

\section{Anbefalede krav til systemet set fra et didaktisk synspunkt}

Set fra et naturfagsdidaktisk perspektiv, kan en e-learning-platform levere særlig værdi til uddannelse og undervisning hvis systemet indholder portefølje for både studerende og undervisere, kommunikation mellem undervisningsdeltagere samt evaluering.

- En personlig portefølje af elektroniske materialer med en god historik indbygget vil være et meget anvendeligt værktøj under uddannelsen, både for underviser og studerende. Den skal kunne håndtere oplagte filer, men også kommunikation og evalueringer fra et bestemt kursus. Der bør ingen begrænsninger være i hvilke typer af filer platformen kan håndtere.

- Kommunikationsdelen i e-learning-platformen skal være veludbygget og det skal være nemt at overskue hvilken kommunikation der foregår og er foregået, også når man er medlem af mange fora.

- Evalueringsmuligheder i systemet er meget vigtige i forhold til hvor udbredt vi kan forvente anvendelse af en e-learning-platform vil blive. Det bør være let at oprette evalueringer og muligt at anvende alle typiske testformer (lukkede/åbne spørgsmål, udfyldningsopgaver, sammenkædningsopgaver, brug af billeder, film og audio, osv.), inkl. matematisk formatering.

- Kurset skal oprettes automatisk med tilhørende funktioner, så det er nemt for underviseren at gå til det.

- Platformen skal kunne håndtere alle filtyper.

- For symboltunge fag, som fx. matematik, fysik og kemi er det væsentligt at systemet kan håndtere matematiske symboler og formler, fx når opgaver skal afleveres, eller tests køres over systemet. Det samme gælder anvendelsen af grafiske præsentationer.

- Eksport/import af kursusmateriale og studenterproduktioner (kursusbeskrivelser, evalueringer, kommunikation, nyheder, osv.) er afgørende. 


\section{I den ideelle e-learning-platform...}

...vil en studerende

- være oprettet i systemet allerede inden kurset påbegyndes (dvs. ved indskrivning til studiet) *

- $\quad$ kunne søge på kurser *

- $\quad$ kunne melde sig til kurser*

- have adgang til on-line ressourcer for det pågældende kursus, fx:

1. applikationer (MatLab, ArcView GIS, fagaktuelle databaser, etc.)

2. kursusdokumenter

3. diskussionsfora - med mulighed for

- søgning i alle diskussioner

- fleksibel listning (fx. efter emne, forfatter, oprettelsestidspunkt, læste/ulæste)

- at det er tydeligt hvem der siger hvad (fx. med farveangivelse)

4. mulighed for at modtage / aflevere opgaver

5. kunne oplægge og hente alle dokumenttyper (video, præsentationer, grafik, animationer mv.)

6. søgemulighed inden for det aktuelle kursus

7. muligheder for at kunne søge yderligere fagrelateret information på Internettet

8. evt. have mulighed for at være anonym i en diskussion / kursusevaluering

9. kunne oprette egne grupper til diskussioner osv.

10. kunne se hvilke andre brugere der er logget på

- have adgang til eget hjemmedrev (privat filområde, som systemet stiller til rådighed)

- $\quad$ kunne melde sig til eksamen *

- $\quad$ kunne evaluere det pågældende kursus *

- $\quad$ se oversigt over evalueringerne af alle kurser (egne og andres) *

- $\quad$ se egne afsluttede kurser, karakterer og opgaveafleveringer (historik / portefølje) *

- have global søgemulighed inden for platformen, dog kun med adgang til relevante dele

- $\quad$ kunne få besked fra systemet via SMS

- $\quad$ have mulighed for personlig tilretning

\section{... og underviserne vil kunne:}

- $\quad$ oprette brugere (til test etc.)

- $\quad$ ændre brugeres rettigheder ( $\mathrm{fx}$ fra studerende $\rightarrow$ instruktor og vice versa)

- fjerne studerende der ikke retmæssigt hører til på et kursus, eller som er frameldt

- $\quad$ begrænse for adgang til kursus

- oplægge materiale uden kendskab til HTML og uden særlige programmer installeret

- $\quad$ annoncere begivenheder

- oplægge nyt/redigere eksisterende materiale

- kontrollere hvem der må downloade kursusmateriale

- $\quad$ inddele delmængder af de studerende på kurset i grupper med egne diskussionsfora mv.

- $\quad$ kommunikere med alle eller dele af de studerende

- lave evalueringer med alle typiske testformer (lukkede/åbne spørgsmål, udfyldningsopgaver, sammenkædningsopgaver, brug af billeder, film, audio, matematisk formatering).

- genbruge spørgsmål fra evalueringer

- $\quad$ anvende matematisk formatering $i$ tekst

- få statistik på systemets anvendelse

- $\quad$ se hvem der har meldt sig til eksamen *

- få oversigt over standpunktet for studerende i eget kursus

- se evalueringsresultater

- kunne vælge om kurset skal være lukket / halvåbent (fx. kommunikationsdelen lukket) / åbent

- $\quad$ kunne gemme kursusmateriale / tidligere diskussioner til senere brug, uden at de studerende har adgang til det

\section{Tekstboks 2: Den ideelle e-learning-platform}




\section{Den ideelle e-learning-platform}

Tekstboks 2 summerer vores bud på krav til en e-learning-platforms brugsmæssige og tekniske kunnen med udgangspunkt i hhv. studenter- og underviserrollen.

Tegnet * markerer de funktionaliteter, der forudsætter en kobling til administrative systemer. Kravene beskrevet i det ovenstående danner grundlag for udarbejdelsen af et spørgeskema med 32 spørgsmål som de udvalgte systemer efterfølgende er blevet evalueret efter. Spørgeskemaet er vedlagt som bilag 1.

\section{Systemadministration}

Den valgte e-learning-platform skal have en administrativ tilgang, der afspejler universitetets administrative opbygning. For KUs vedkommende er det vigtigt, at oprettelse og nedlæggelse af kurser kan ske i de enkelte miljøer og ikke kun hos få administratorer, da dette vil skabe en flaskehals. For at sikre, at undergrupperne kun kan administrere kurser hos egen undergruppe, er det nødvendigt med en træstruktur, som vist i figur 1.

Universitetssadministratoren har superbrugerrettigheder i systemet og kan således oprette og slette kurser og personer på alle niveauer. Fakultetsadministratoren kan administrere til alle institutter under det pågældende fakultet, men har ikke adgang til administration af andre fakulteters kurser og kursusdeltagere. Institutadministratoren kan administrere systemet til alle underliggende afdelinger på eget institut, men har ikke adgang til administration af andre institutters kurser og kursusdeltagere.

Afdelingsadminstratoren kan administrere systemet indenfor egen afdeling (et eksempel på en afdeling kunne være populationsøkologi under Zoologisk Institut). Det er tanken at afdelingsadministratoren vil være den daglige kontaktperson, når nye kurser og/eller personer skal oprettes. Platformen skal kunne udbygges til at omfatte administratorer på flere niveauer, hvis der er behov herfor.

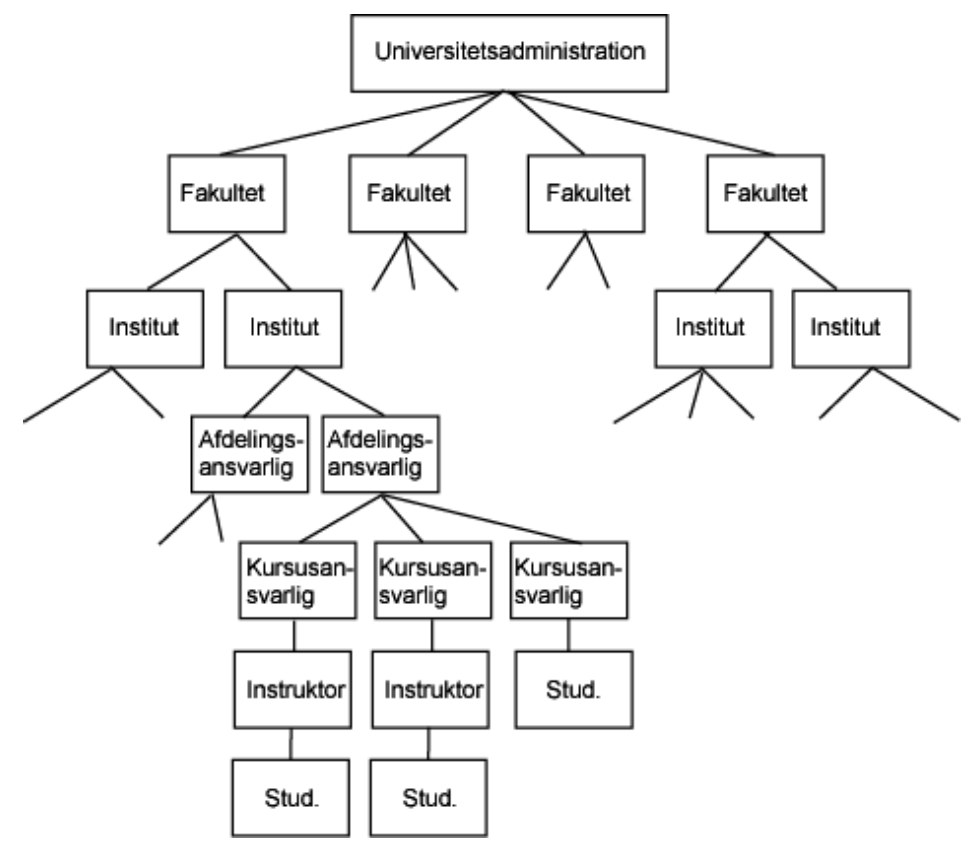

Figur 1: Ønsket adminstrativ opbygning af en e-learning-platform 


\section{Kursusadministration}

Systemet skal opfylde et behov om forskellige underviserroller. Typisk vil et kursus have en kursusansvarlig, der tager nogle eller alle forelæsninger, men ikke nødvendigvis forestår øvelsesundervisningen. Denne varetages ofte af forskellige undervisere, og der vil derfor være behov for at systemet kan tackle, at forskellige personer har adgang til at oplægge materiale i systemet, men ikke nødvendigvis adgang til alle dele af systemet. Disse rettigheder bør kunne ændres af den kursusansvarlige.

\section{Evaluering af udvalgte systemer}

Med udgangspunkt i ovenstående er 9 systemer blevet evalueret. Systemerne repræsenteres af tre større amerikanske, tre nordiske, 1 open source samt 2 KU-udviklede. De systemer der indgår i undersøgelsen er nævnt i tabel 1 med angivelse af udbyder.

Tabel 1: Oversigt over systemer der er indgået i evalueringen

\begin{tabular}{|c|c|}
\hline System & Udbyder \\
\hline 1. Blackboard 6 Enterprise & Blackboard Inc. \\
\hline 2. CampusNet & Arcanic \\
\hline 3. DotLRN & MIT (Massachusetts Institute of Technology) \\
\hline 4. Fronter & Fronter $\mathrm{A} / \mathrm{S}$ \\
\hline 5. ISISk & ISISk-styregruppen, Det Naturvid. Fakultet, KU \\
\hline 6. Luvit & Luvit $A B$ \\
\hline 7. Oracle iLearning & Oracle \\
\hline 8. PUNKT KU & KU \\
\hline 9. SiteScape & SiteScape Inc. \\
\hline
\end{tabular}

Ved evalueringen af systemerne er der indhentet oplysninger dels fra systemudbyderne og dels fra personer der er pædagogiske eller tekniske konsulenter på systemerne i en universitetssammenhæng.

\section{Resultater af undersøgelsen}

Efter gennemgangen af de ni systemer er der ikke én kandidat der skiller sig klart ud fra de andre. Imidlertid er der en række systemer der har så klare fordele, at NIK mener de vil være egnede som elearning-platform til brug i naturvidenskabelig universitetsundervisning. De funktionaliteter der har været afgørende for egnetheden i sidste ende har været, at systemet

- understøttes af internationalt anerkendte standarder

- giver mulighed for indflydelse på den fremtidige udvikling

- er udviklet til universitetsundervisning

- giver mulighed for samarbejde omkring platformen med andre universiteter

- er omkostningseffektiv

Tabel 2 angiver NIKs placering af de undersøgte systemer vist i tabel 1, ift. ovenstående første 4 punkter. 


\begin{tabular}{|c|c|c|c|c|c|c|c|c|c|}
\hline & $\begin{array}{l}\text { 밈 } \\
\frac{0}{0} \\
\frac{0}{0} \\
\frac{\pi}{0}\end{array}$ & 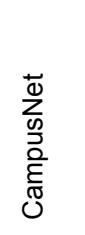 & 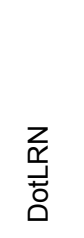 & 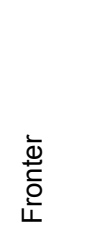 & $\frac{\underline{\omega}}{\underline{\omega}}$ & 荨 & 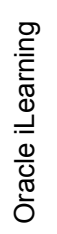 & 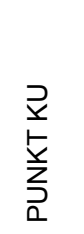 & 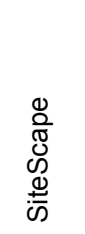 \\
\hline Understøttes af standarder & ja & ja & (ja) & ja & $?$ & ja & $?$ & nej & nej \\
\hline Indflydelse på udvikling & lidt & nogen & meget & noget & meget & nogen & lidt & meget & nogen \\
\hline Udviklet til universitetsundervisning & ja & ja & ja & ja & ja & ja & nej & ja & nej \\
\hline $\begin{array}{l}\text { Samarbejde med andre universiteter } \\
{ }^{*} \text { indicerer uden for DK }\end{array}$ & ja & ja & $\mathrm{ja}^{*}$ & $\mathrm{ja}^{*}$ & nej & $\mathrm{ja}^{*}$ & nej & nej & ja \\
\hline
\end{tabular}

Tabel 2: Sammenligning af systemerne ud fra udvalgte kriterier

Vi stiller nu vores erfaringer til rådighed for det videre arbejde med at finde en relevant e-learningplatform til undervisningen på Københavns Universitet.

\section{Kildehenvisninger}

Collis, Betty \& Jef Moonen (2001): Flexible Learning in a digital world. Experiences and expectations.

\section{Bilag 1. Spørgeskema til vurdering af systemerne}

\section{Selve systemet}

1. Er systemet bygget på en standard? Hvilke(n)?

2. Hvilke sprog er der mulighed for at vælge?

3. Er der global søgemulighed?

4. Kan man modtage/aflevere opgaver?

5. Er der mulighed for at komme med anonyme indlæg i en diskussion?

6. Kan underviseren bestemme hvilke menuer der skal være synlige?

7. Kan den studerende bestemme hvordan siderne skal vises?

8. Mulighed for personlig portefølje (lagring af tidligere kurser med al komm., karakterer etc.)?

9. Kan man få SMS-beskeder med opslag etc?

10. Kan man udvikle evalueringer i systemet?

a. Kan evalueringerne eksporteres mellem kurser?

b. Kan man bruge matematisk formatering i evalueringer?

11. Kan hele biblioteker med dokumenter flyttes rundt inden for kurset? Og mellem kurser?

12. Kan der synkroniseres med kalender etc. i fx. Outlook?

13. Kan man vælge om kurset skal være lukket / halvåbent?

14. Er der nem browsing i oplagte billeder (a la thumbnails i Win Explorer)?

15. Hvilke planer er der for den fremtidige udvikling (næste $12 \mathrm{mdr}$.)? 


\section{Administrationsdelen}

16. Kan vi selv bestemme hvordan layoutet skal være?

17. Kan vi selv bestemme hvad systemet skal hedde?

18. Hvor mange samtidige brugere er systemet testet ved?

19. Kan man restore enkelte kurser?

20. Hvad er systemets oppetid?

21. Hvor sikkert er systemet for hacking?

22. Er der mulighed for graduering i rettigheder i en træstruktur?

23. Hvilke servere kan systemet køre på?

a. Hvilke platforme virker systemet på (Windows, Linux, Mac, Unix)?

b. Kræves særlige players installeret?

c. Kan systemet bruges ved skærmopløsning på $800 * 600$ dpi?

24. Systemet skal sammenkobles med vores administrative systemer (Fønix + SIS). Er systemet så åbent at vi selv kan stå for dette?

25. Er der mulighed for egen videreudvikling eller er vi afhængige af systemleverandør?

26. Kan / skal man selv stå for al support af system og brugere?

27. Kan support være baseret på systemleverandør? I givet fald hvad er prisen?

28. Hvad er anskaffelsesprisen?

29. Hvad er den årlige licens? Hvad rummer denne (opgraderinger etc.)?

30. Er der fuld systemadgang for os (lokal administration)?

\section{Andet}

31. Hvor bruges systemet i Danmark?

32. Hvilke universiteter i Norden bruger det? 